Dom. Cien., ISSN: 2477-8818

Vol. 4, núm.3., jul, 2018, pp. 264-277

The effects of the TPRS Method on the Students' English Vocabulary Acquisition

\title{
The effects of the TPRS Method on the Students' English Vocabulary Acquisition
}

\section{Los efectos del método TPRS en la adquisición de vocabulario en inglés de los estudiantes}

\section{Os efeitos do método TPRS na aquisição de vocabulário de inglês dos alunos}

\author{
Mónica A. Pinos-Ortiz ${ }^{\mathrm{I}}$ \\ monicapinos75@hotmail.com \\ Mariory P. Orbe-Guaraca II \\ mporbeg@ucacue.edu.ec
}

Recibido: 27 de febrero de 2018 * Corregido: 18 de mayo de 2018 * Aceptado: 15 de julio de 2018

Licenciada en Ciencias de la Educación Mención Ingles, Universidad Católica de Cuenca, Cuenca, Ecuador.

II. Magister en Gestión Empresarial, Ingeniero Empresarial; Técnico Superior en Secretariado Ejecutivo Bilingüe, Docente de la Universidad Católica de Cuenca, Cuenca, Ecuador. 


\begin{abstract}
The present study investigates the effects the method of teaching language through reading and storytelling (TPRS) in the acquisition of English vocabulary has in second level students in the Catholic University of Cuenca, extension Cañar; and the perceptions that students have when they are taught through this method. The teaching of language through reading and storytelling is a method that uses different resources for language teaching, providing comprehensible input information in imaginary or real situations derived from students' social context and their cognitive and affective needs. 56 students of the second level of the aforementioned university were randomly selected. A group of 30 students formed the experimental group and 26 students the control group. The data was obtained through the Cambridge vocabulary test in the pre and post-test phases to establish the difference between the groups. Additionally, a survey was applied to the students of the intervention group to know their perspectives on the method. The independent t-statistic test was used for the data analysis. The results show that the students of the treatment group obtained better results than the students in the control group in the measures of vocabulary acquisition. Additionally, the results of the survey showed that the students perceive that the strategies derived from the method were of great support to acquire vocabulary in English.
\end{abstract}

Keywords: Teaching, Learning, Vocabulary, English, Reading. 


\section{Resumen}

En el presente estudio se investiga los efectos que tiene el método de enseñanza del idioma a través de la lectura y la narración de cuentos (TPRS por sus siglas en inglés) tiene en la adquisición de vocabulario del inglés en los estudiantes de segundo nivel en la Universidad Católica de Cuenca, extensión Cañar; y las percepciones que los estudiantes tienen cuando son enseñados con este método. La enseñanza del idioma a través de la lectura y la narración de cuentos es un método que utiliza diferentes recursos para la enseñanza de lenguas, proporcionando información de entrada comprensible en situaciones imaginarias o reales derivadas del contexto social de los estudiantes y sus necesidades cognitivas y afectivas. Fueron seleccionados al azar 56 estudiantes del segundo nivel de la universidad antes mencionada. Un grupo de 30 estudiantes conformaron el grupo experimental y 26 estudiantes el grupo de control. Los datos se obtuvieron a través de la prueba de vocabulario de Cambridge en las fases de pre y post prueba para establecer diferencia entre los grupos. Adicionalmente, una encuesta fue aplicada a los estudiantes del grupo de intervención para conocer sus perspectivas sobre el método. La prueba estadística t independiente se utilizó para el análisis de datos. Los resultados muestran que los estudiantes del grupo de tratamiento obtuvieron mejores resultados que los estudiantes en el grupo control en las medidas de adquisición de vocabulario. Adicionalmente, resultados de la encuesta demostraron que los estudiantes perciben que las estrategias derivadas del método fueron de gran apoyo para adquirir vocabulario en inglés.

Palabras claves: Enseñanza, Aprendizaje, Vocabulario, Inglés, Lectura. 


\section{Introduction.}

The study of English has been taking more and more importance among Spanish speakers at all levels. It is well known that the mastery of English as a foreign language is a tool that offers advantages to people in different ways, since globalization has been increasingly involving the whole world. So that, many studies have been carried out that help with the creation of innovative strategies to facilitate and stimulate the teaching and learning processes of languages, with English being the most popular in the world, as stated by McCrum, Cran and MacNeil (2003) "...it has become the language of the planet, the first truly global language" (p.21).

Many countries have implemented reforms to include the study of English in their pensum; and Ecuador is one of them. In an article published by the British Council 2015 in this country, the importance of English teachers making an effort to apply the best methods during the classes is highlighted, in order to satisfy the needs of their students and facilitate the teaching and learning processes of a foreign language; In addition to training people with sufficient reading capacity to address research issues, and even make them competitive in their work field.

In Ecuador, for example, students of the University Education System are required to have a certain level of English as a foreign language in order to continue their studies. So, in 2014, the Catholic University of Cuenca created a system that guarantees that each student must complete four levels of English; but despite the fact that numerous strategies and methods have been put into practice to contribute to the development of the four linguistic skills for teaching and learning this language (listening, speaking, reading and writing), there are still weaknesses that must be addressed to improve the process of acquiring it. 
In fact, it was determined, from the results of a previous study, the direct observation in classrooms and interviews made to both, students and professors, that the students of the second level of English in this University, present deficiencies in terms of the acquisition of vocabulary, which limits the communication of students, inhibiting them from using English effectively.

Therefore, the present study has as purpose to provide a tool for the acquisition of vocabulary in English, since without vocabulary the language could not exist, since it is the words that give meaning to the language. In 1990, Teaching Proficiency through Reading and Storytelling (TPRS) was created. Ray and Seely (2012) affirm that the use of TPRS in classrooms is a method that can be used by teachers so that they can enrich the vocabulary of their students in an interesting way.

In order to develop this investigation, the most important precedents related to the subject matter of this investigation were considered. These focused on determining the effects of the TPRS Method on the students' English vocabulary Acquisition at the Catholic University of Cuenca, Cañar Extension as a favorable strategy to teach the English language. In addition, its reading and writing skills establishing the use of the TPRS Method in vocabulary Acquisition as an alternative to teach and learn foreign languages at the university level.

Several studies about TPRS and its influence on vocabulary acquisition have been developed; for instance, Heiser (2001) showed that TPRS improves pronunciation and vocabulary retention. He claims for the integration of grammar using it. Moreover, Watson (2009) compared TPRS to traditional teaching proving that the first is better in vocabulary learning. Additionally, Varguez (2009) studied the relation between TPRS and learners' socioeconomic conditions. Braunstein (2006) informed that even adult ESL students who 
expected more traditional instruction responded positively to TPRS. Furthermore, Merinnage De Costa (2015) compared TPRS against traditional methods at a Public University in the Midwestern United States in an introductory college level.

He reported that the experimental group which used TPRS showed superior developments on measures of listening, vocabulary, culture, grammar and writing skills. Besides, Dukes (2012) explored the feelings and perceptions students have when being taught with TPRS as a stand-along methodology at a high school foreign language classroom, in the state of Utah. The study revealed that students enjoyed learning a foreign language through TPRS, and they experienced a more significant English understanding.

It is necessary to highlight the importance that these investigations have for this research, as, they propose the educational use of TPRS as a natural learning method that uses innovation, creativity, and dynamism to teach a language.

The above precedents constitute an important indicator when it is time to determine the impact of the TPRS method in the acquisition of English vocabulary in second level students at the Catholic University of Cuenca, as they leave evidence of the implementation of a different English-teaching method and its implications in the classrooms and in this way be able to propose the implementation of the TPRS method in the universities of Ecuador as an educational tool for the teaching of English.

All that, led the author of this thesis to investigate the effects that the Teaching Proficiency through Reading and Storytelling (TPRS) method has on the second level students' English vocabulary acquisition at the Catholic University of Cuenca. She is seeking to determine the benefits 
of including TPRS regarding the acquisition of English vocabulary, and the perception they have about using this method.

\section{Method}

During the investigation, a group of 56 students was taken, students of the second level of English of this University; divided into two groups, 30 students were selected as an experimental group, they were exposed to the TPRS during their classes, and another 26 students who formed the control group. This process was carried out from October 2016, until February 2017, that is 32 academic hours in a period of 8 consecutive weeks.

The paradigm used was the post-positivist, and the design was quantitative; in which a pretest and a post-test were applied to establish the effects that the use of TPRS had in the classroom of the second level of English of the Catholic University of Cuenca, extension Cañar, Ecuador. The test was based on the book entitled Touchstone 2B by MacCarthy, MacCarten and Sandiford (2014), which is the one used in the Languages Department of the University.

In addition, after working with TPRS in the classroom, a survey was applied to the students of the experimental group, to know their perception of the method used to acquire vocabulary. The questionnaire was an adaptation of Dukes 2012.

\section{Results.}

The results obtained after applying both the control group and the experimental group, a pre-test and a post-test on the acquisition of the vocabulary contained in the book Touchstone English Level II, as well as a survey to know the students' perception During the implementation of the TPRS method were the following: 
The pre-test applied to both groups before beginning the study, in order to measure the knowledge in terms of the vocabulary they had to handle, showed that they were almost at the same level, obtaining the experimental group an average of 13.5 and the control group 11.0 , as shown in the following table.

Table1. Mean and Standard deviation in pre-test stage

\begin{tabular}{llccc}
\hline & Group & N & Mean & $\begin{array}{l}\text { Standard } \\
\text { Deviation }\end{array}$ \\
\hline Score & Control & 26 & 11.0 & 3.5 \\
& Experimental & 30 & 13.5 & 4.5 \\
\hline
\end{tabular}

Source: SPSS

Table 2. Pre-post- test results - control group

\begin{tabular}{llll}
\hline Control Group & N & Mean & $\begin{array}{l}\text { Standard } \\
\text { Deviation }\end{array}$ \\
\hline Pretest & 26 & 11.0385 & 3.51546 \\
Posttest & 26 & 18.6154 & 1.83471 \\
\hline
\end{tabular}

Source: SPSS

Table 3. Pre-post- test results - Experimental group

\begin{tabular}{|c|c|c|c|c|}
\hline & & & & Standard \\
\hline Experimental & $\underline{\mathbf{N}}$ & Mean & Deviation & \\
\hline
\end{tabular}




\begin{tabular}{llll}
\hline Pretest & 30 & 13.5667 & 4.51575 \\
Posttest & 30 & 25.7667 & 6.52678 \\
\hline
\end{tabular}

Source: SPSS

As can be seen in table 2, the average score of the control group was raised, from 11.0385 to 18.6154 after the class; while Table 3 reveals a greater increase in the experimental group, from 13.5667 obtained before applying the TPRS method, it happened to have 25.7667 in the post-test, which is quite significant.

On the other hand, it was applied a survey to find out how the students of the experimental group felt during the implementation of the TPRS method. This survey consisted of 8 questions:

- Question 1: I think the teaching method used in class creates a comfortable atmosphere for learning the English language.

- Question 2: I feel comfortable performing the body movements according to the vocabulary

- Question 3: I feel comfortable contributing with the story creation.

- Question 4: I think storytelling helps me learn the English language.

- Question 5: I think that listening and trying to understand what is said in the English language helps me learn its vocabulary.

- Question 6: I feel that I understand most of the English words said in the classroom. 
The effects of the TPRS Method on the Students' English Vocabulary Acquisition

- Question 7: I feel that reading the stories created in class helps me learn the English vocabulary.

- Question 8: I think that the TPRS method helps me learn the English vocabulary.

There were 5 possible answers, on a scale from 0 to 25 :

- Strongly agree

- Agree

- Neutral

- Desagree

- Strongly desagree

\section{Summary of the Percentages of Student survey results}




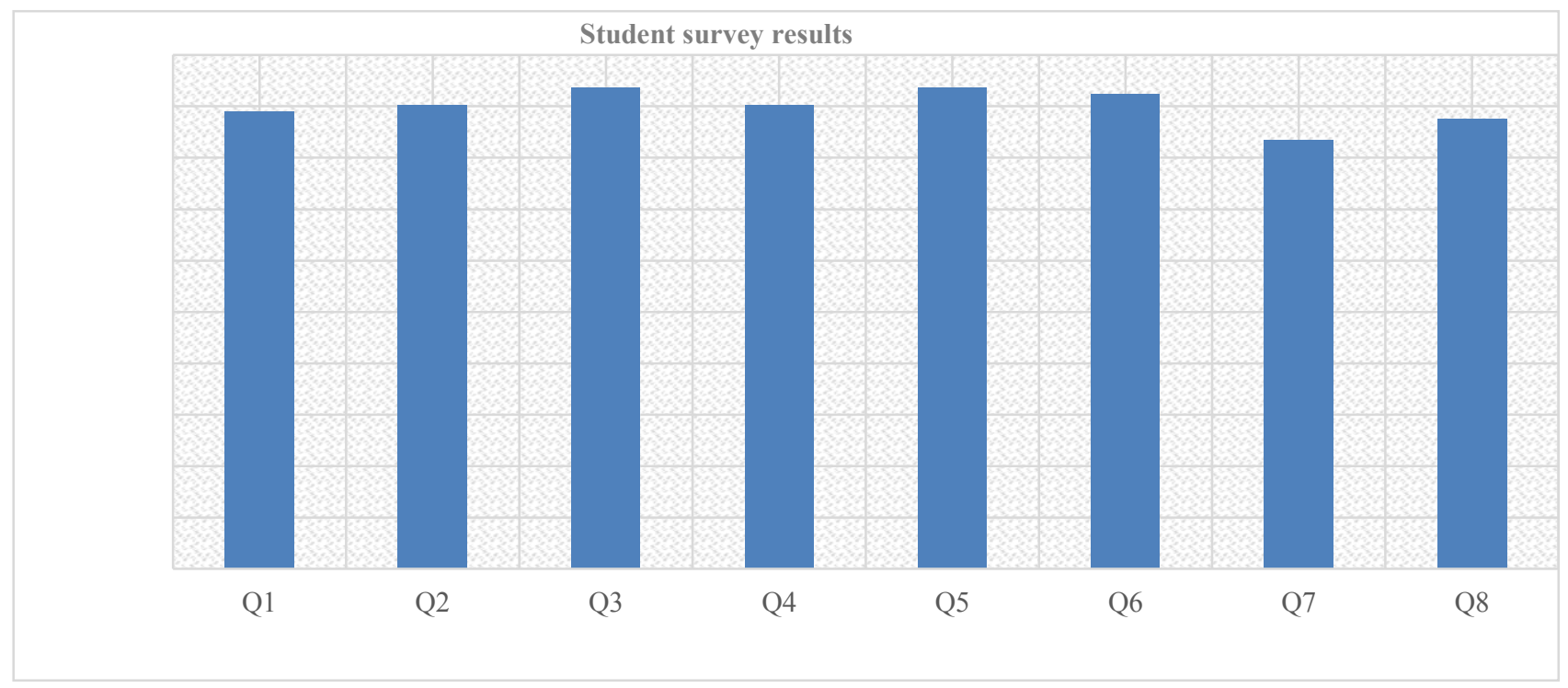

Figure 1, Student survey results

In the previous figure it can be seen that most of the students of the experimental group in this study agree that the TPRS method contributes to significantly improve the acquisition of vocabulary in English.

\section{Discussion and Conclusions}

The present study emerged from the need to determine the effect that the application of the TPRS method has on the classes, in order to achieve that the students of the second level of English of the University of Cuenca, Ecuador, expand their vocabulary and can communicate better, and Therefore, be more participatory and perform interventions in the classroom. 
Additionally, the new regulation of the Academic Regimen (2015) states that university students must demonstrate foreign language B1 level according to the Common European Framework of Reference before they reach sixty percent of their total credits have motivated the researcher to find an instructional methodology that increases the students' English vocabulary acquisition.

The TPRS method is developed in three steps that are the following:

- The first step is the presentation of the vocabulary; this can be done through keywords, gestures, flash cards, among others.

- The second step is to create a story together with the students.

- And finally, as a third step, the story is read by all, so that learners can appreciate the applicability of the vocabulary in context.

In this section the two research questions will be answered:

- Do English vocabulary scores for students taught with the TPRS method differ from English vocabulary scores of students taught without it?

- What perceptions do second level students have when being taught English vocabulary using the Teaching Proficiency through Reading and Storytelling instruction?

Taking into consideration the outcomes from the statistical examination, these indicate that second level students in the experimental group English vocabulary acquisition has been enriched 
with the use of the TPRS method since their vocabulary scores in the post-test greatly differ from the vocabulary scores of students in the control group.

Watson (2009) compared TPRS method to traditional teaching. She demonstrated that the use of TPRS improves vocabulary learning.

In relation to the second research question students' perceptions towards the TPRS method were considered. The results of the questionnaire were positive for all the questions students were asked. These responses in the questionnaire mean that students have a positive perception of the TRPS method by itself. Most importantly, the students expressed that they really achieved an increase in their knowledge of vocabulary which, in turn, leads to the improvement of their English language skills.

Finally, the TPRS method gives enough comprehensible input and personalized learning to the student because the instructor takes the necessary time to explain to students in detail so that the students really acquire the knowledge the instructor wants them to have.

\section{Referencias.}

Braunstein. (2006). Adult ESL Learners'attitudes towards movement (TPR) and drama (TPR Storytelling) in the classroom. CATESOL 18 (1), pp. 7-20.

British Council. (2015). English in Ecuador: An examination of policy, perceptions and influencing factors. (Research Report). Retrieved from: https://ei.britishcouncil.org/sites/default/files/latin-americaresearch/English\%20in\%20Ecuador.pdf.

Heiser, D. J. (2001). Teaching German with TPRS (total physical response storytelling). Die Unterrichtspraxis/Teaching German, pp. 25-35.

MacCrum, R., Cran, W., \& MacNeil, R. 2. (2003). The story of English . USA: Penguin Group.

McCarthy, M., MacCarten , J., \& Sandiford, H. (2012). Touchstone. New York: Cambridge University Press. 
Merinnage De Costa, R. S. (2015). Traditional Methods Versus TPRS: Effects on Introductory French Students at a Medium-Sized Public University in the Midwestern United States. (Doctoral dissertation, Minnesota State University, Mankato).

Ray, B., \& Seely, C. (2012). Fluency through TPR storytelling: Achieving real language. Eagle Mountain: UT: Blaine Ray Workshops and Berkeley, CA: Command Performance Language Institute.

Varguez, K. C. (2009). Traditional and TPR Storytelling instrucction in high school classroom. The International Journal of Foreign Language Teaching, 5(1), pp. 2-11.

Watson, B. (2009). The International Journal of Foreign Language Teaching. Retrieved from The International Journal of Foreign Language Teaching: https://25a0znx4xieuz.cloudfront.net/wp-content/uploads/2013/04/Comparison-TPRS-vsTraditional-B.Watson.pdf 